\title{
Fire against rural areas - proposal: Protection of rural properties against forest fires
}

\author{
Sistema contra incêndios para áreas rurais - proposta: Proteção de propriedades rurais contra \\ incêndios florestais
}

Sistema de lucha contra incendios para zonas rurales - propuesta: Protección de propiedades rurales incendios forestales

Odailson de Almeida Melo

ORCID: https://orcid.org/0000-0002-1182-5150 Universidad Paulista, Brazil

E-mail: amazontecoda@gmail.com

Alexandra Amaro de Lima

ORCID: https://orcid.org/0000-0003-3918-0013 Universidad Paulista, Brazil E-mail: xanduca@gmail.com

Arleson Ferreira Maquiné ORCID: https://orcid.org/0000-0001-7609-0602 Universidad Paulista, Brazil E-mail: arleson@gmail.com

Closival Romano Barreto

ORCID: https://orcid.org/0000-0002-7924-7633 Universidad Paulista, Brazil E-mail: arleson@gmail.com

Herbert Rodrigues Mendonça ORCID: https://orcid.org/0000-0002-6408-494X Universidad Paulista, Brazil

E-mail: herbert.rodrigues@gmail.com

João Wilson Fernandes de Morais ORCID: https://orcid.org/0000-0002-1702-0839 Universidad Paulista, Brazil

E-mail: jmorais18@hotmail.com

Renato Nelson Farias Cavalcante Filho ORCID: https://orcid.org/0000-0001-6391-3577 Universidad Paulista, Brazil

E-mail: renatofilho96@hotmail.com Luciana da Silva Reis

ORCID: https://orcid.org/0000-0001-6671-1516 Universidad Paulista, Brazil

E-mail: lucianasreis@gmail.com

Fernando Pauxis

ORCID: https://orcid.org/0000-0001-6079-4357 Universidad Paulista, Brazil

E-mail: fernando.pauxis@gmail.com

\begin{abstract}
This article describes a fire system developed to be used in rural areas. During the dry season (Southern Hemisphere winter months) in the north and Midwest regions, fire events in rural properties, usually cause incalculable economic and environment damage. The system is a fence composed of water pipes installed around the property, which is connected to a temperature and hydraulic Arduino sensors linked to a pump. Temperature sensors installed next to the enclosure are responsible for activating and deactivating the system in a fire occurrence event close to the enclosures (defense). As temperature decreases, there is an absence of fire, and the sensors turn off the hydraulic pumps and water transport ceases. In addition, the system is practical and can be activated any time using technologies such as GPRS and Bluetooth, and at the same time, sends alerts in cases of new fires.
\end{abstract}

Keywords: Automatic system; Forest fire; Rural property; Protection.

\section{Resumo}

O presente artigo mostrará a criação de um sistema contra incêndio em áreas rurais. Durante a estação seca (meses de inverno no hemisfério sul) as regiões norte e centro-oeste os focos de incêndios em propriedades agrícolas, causando prejuízos incalculáveis ao meio ambiente e aos produtores. O sistema desenvolvido é um cercado composto por 
tubulações de água instaladas em torno da propriedade, o qual é conectado a juntamente a sensores Arduínos de temperatura e sensores de acionamento das bombas hidráulicas. Os sensores de temperatura são instalados junto ao cercado sendo os principais responsáveis pela ativação e desativação do sistema caso haja a presença de fogo próximos aos cercados (linha de defesa). À medida que a temperatura diminuí, configura-se a ausência de fogo e os sensores desligam as bombas hidráulicas e cessa o transporte de água. Além disso, o sistema é prático e pode ser acionado a qualquer momento através de tecnologias, como GPRS e Bluetooth, e ao mesmo tempo, envia alertas o proprietário em casos de novos focos de queimadas.

Palavras-chave: Sistema automático; Incêndio florestal; Propriedade rural; Proteção.

\section{Resumen}

Este artículo mostrará la creación de un sistema de extinción de incendios en zonas rurales. Durante la estación seca (meses de invierno en el hemisferio sur) las regiones norte y centro-oeste del país tienen incendios en propiedades agrícolas, causando daños incalculables al medio ambiente y a los productores. El sistema desarrollado es un recinto compuesto por tuberías de agua instaladas alrededor de la propiedad, que se conecta junto con sensores de temperatura Arduino y sensores de activación de la bomba hidráulica. Los sensores de temperatura están instalados junto al recinto y son los principales responsables de activar y desactivar el sistema en caso de que se produzca un incendio cerca del recinto (línea de defensa). A medida que la temperatura desciende, no hay fuego y los sensores apagan las bombas hidráulicas y cesa el transporte de agua. Además, el sistema es práctico y se puede activar en cualquier momento a través de tecnologías como GPRS y Bluetooth, y al mismo tiempo envía alertas al propietario en caso de nuevos incendios.

Palabras clave: Sistema automático; Incendio forestal; Propiedad rural; Protección.

\section{Introduction}

Recent decades have seen an increase in fires been used by farmers as a strategy for cleaning the off-season field, for being efficient in removing residues and, the resulting ashes have considerable fertilizing power (Abreu and Souza, 2016; Cochrane, 2010; Ribiero and Bomfim, 2000). In addition, fires are an instrument used in the occupation of preserving areas by land grabbers ("grileiros"), irregularly harvested timber (Marques and Sobrinho, 2020) and expansion of agricultural frontiers (Neves et al., 2018). This practice is still carried out by cattle ranchers to burn forage, both native and cultivated, periodically, when they become fibrous and lignified, relying on the new sprouts of the pasture to feed the herd (Rego and Kato 2018; Silva and Pontes, 2020). The aggravating factor of burning controlled is that they can escape the control (accidentally or induced), burning the surrounding vegetation, in addition to increasing its intensity when there are remains of the logging (Silva and Pontes, 2020; Jesus et. al., 2020; Adams and Murrieta, 2008).

However, the use of controlled fires in agriculture and livestock can bring damage to the soil, such as its impoverishment due to physical and caused by fires (Spera et al., 2000; Stone and Silveira, 2001), in addition to the most irreparable damage that is the loss of natural biome (Rezende, 2017). The smoke produced is potentially damage to the environment due to its impact on the greenhouse gases concentration in the atmosphere, as well as people's health increasing exponentially respiratory diseases cases (Mélo et al., 2011; Gioda et al., 2019; Corrêa et al., 2021, Santiago and Lopes, 2021).

Anthropogenic sources are not solely responsible for events agroforestry fire, in addition to them natural processes such as electrical discharges in the atmosphere-ground interface during dry season in the amazon region (Southern Hemisphere winter), are responsible for natural fires (Medeiros and Fieldler, 2004; Stephens, 2005; Abatzoglou et al., 2016). In countries like Canada and Australia natural fires are responsible for 50\% and 30\% of burnt areas (Ganteaume and Syphard, 2018; Dowdy and Mills, 2012b). Brazil has the highest incidence of lightning in the world due to its proximity to the Equatorial Depression, as shown by Pinto Jr and Pinto (2000).

Additionally, there are three factors that cooperate to trigger devastating fires. The first factor is a combination of hot and dry weather, with air humidity below $20 \%$. The second one is the presence of some type of material that will ignite when lightning strikes or through a cigarette played in the cerrado. And finally, the third is the presence of an abundant amount of fuel to the flames, such as tons of flammable wood, shrubs and dry foliage. The factors mentioned above can be aggravated by 
the presence of strong winds that accelerate the spread of flames, such as that which occurred in 1998, in the state of Roraima, where an area of 14 thousand square kilometers. But for Silva Filho et al., (2009), despite the decrease in 2007, the author nevertheless suggests inspection and planning to combat fires.

In Brazil, rural properties in the North, Northeast and Midwest regions annually suffer incalculable damage to fauna, flora and fields caused by forest and out-of-control fires, which are more frequent during the dry season in the Southern Hemisphere (Soares and Peixinho, 2020; IBGE, 2017, Pezzatti, et al 2013; Bretos, 2012). According to the fires dimensions, joint actions to combat propagation and elimination of fires are carried out integrated with state and federal government, trained firefighters from the National Center for Prevention and Fighting Forest Fires (Prevfogo) and the Brazilian Institute of Environment and Renewable Natural Resources for combat. Additionally, orientation campaigns for rural producers on the practice of burning controlled are promoted (Muñoz, 2000). Despite mobilization to control fire outbreaks, efforts are not enough to reduce forest and field losses. At different times, teams have difficulties in identifying, accessing affected areas and eliminate fire outbreaks, which means that many rural properties and conservation areas are destroyed by fire even before the teams arrive (Neto et al., 2017).

An effective tool for monitoring fire outbreaks in regions distant from the urban areas are satellite images. Pioneer in the development of technologies, fire detection systems and other tools is the National Institute for Space Research (INPE). INPE researchers have been developing fire monitoring systems and risk maps by satellite since 1987 (INPE, 2017). Satellites are also used by public and private offices in daily fire monitoring (EMPRAPA, 2016).

In addition, mathematical models, artificial intelligence and even surface sensors (Yu et al., 2005; AlJanabi et al., 2018; Li et al., 2006) are useful in early detection of forest fires. To access this problem, an automatic system for detection and control of local fires has been developed for small rural properties in this region. The system works unassisted and without human intervention, so that it can detect the presence of flame or temperature rise around the implemented site. In addition, the performance of the system will also depend on the general conditions of each location, such as the history and annual frequency of fires, preferential wind direction, type of vegetation, water availability, environmental impacts, etc. For this reason, for the success of system, a prior study should be performed. In this work, the project will be shown and building a system of protection of rural properties against forest fires.

\section{Methodology}

As Gil (2010) teaches, research aimed at acquiring new knowledge directed to broad areas with a view to solving recognized practical problems are classified as strategic basics. This research was also exploratory in nature, because it sought to improve ideas, approach the problem studied (LAKATOS and MARCONI, 2011). In addition, the scientific-technological method is the basis of this study, which sought to materialize a technological artifact that is easy to develop and handle, even when the user does not have scientific knowledge and thus, this technological artifact tries to solve one of the current problems in the country, which are forest fires in rural areas (NASCIMENTO and SILVA, 2020).

For the development of the system, a previous study was carried out based on the information made available by the Environmental Protection Laboratory (2018), to evaluate fire behavior using equations such as the Byram equation that describe the intensity, speed of propagation and residence time of the fire in a particular region. In this way, found restrictions and difficulties in monitoring fire outbreaks were analyzed, in addition to the vulnerability of fauna and producers to fires in Rondônia region. The system was developed for a property in the town of Rondônia state. From such an eminent problem in the region, a system of water jets capable of constantly defend areas of production and rural residence, store water for use in combating outbreaks and monitoring the existence of fire in the surrounding areas all the time, in addition to promoting 
sustainable development in the region. For this, the system will have reservoir, piping and pumping subsystems water, activated by temperature sensors through a control center as shown in Figure 1.

Figure 1 shows a graphic scheme of the rural property used as a model in the development of the fire detection system, from 3 different perspectives. Note that Figure 1a shows the 3 water reservoirs (at the top of the figure), while the shelter beside the inner fence is used to protect the sensors. Figure 1b, on the other hand, highlights the hydraulic system responsible for releasing water in case of fire in the surroundings. In Figure 1c, you can get an overview of the system.

Figure 1: a) Water reservoirs and system command center; b) water pipes and sensors installed in the property's enclosures; c) rural area with a fire system installed.
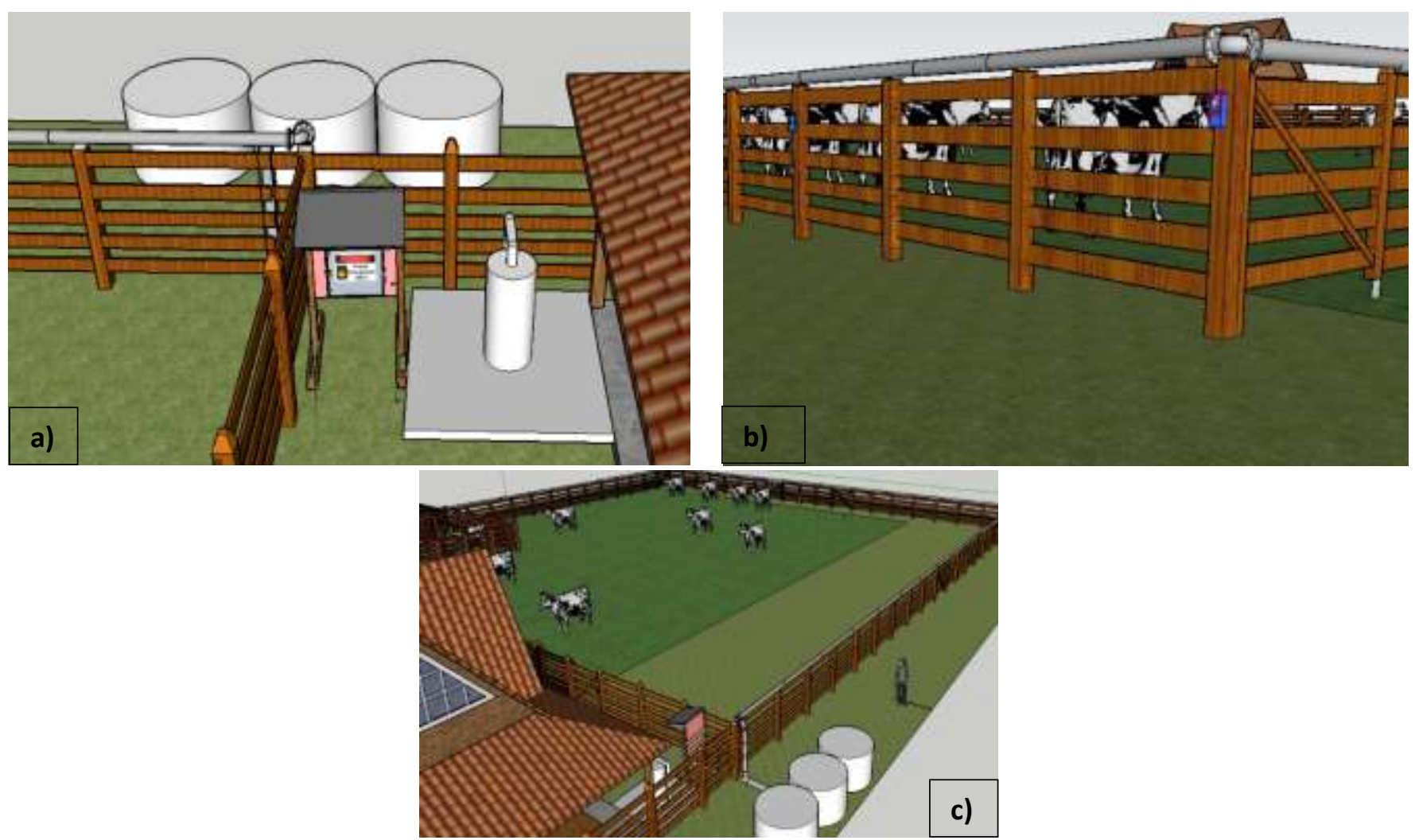

Source: Authors.

The water jets are generated by holes properly distributed along the pipelines installed in the upper part of the property's fences, the system being the system activation configuration according to the needs of each property. Thus, in an area $\geq 7,100 \mathrm{~m}^{2}$, the sensors that activate the water jet system require the support of a hydraulic pump and water reservoir close to the site installed. The distance between the outlet of the jets is determined according to the results functional tests with the device, that is, flow control solenoids activate the water jets only in the section where the sensors detected the presence of fire, not across the area.

\subsection{Delimitation of the study area}

The choice of the installation area of the system must obey the preferred direction of fires. In the case of installing the system in regions close to large vegetation or forest, firebreaks around 3 to 10 can be opened meters wide, between the protection fence and the forest preventing the equipment damaged by the flames, in addition, it allows the sensors to read the surrounding environment. At the same time, this distance also allows the system to evaluate the speed, local wind direction, which allows the system to check the speed of spread of fire and the number of jets that should be activated. The system was 
developed for flat terrain, but can be implemented in areas of relief pronounced, or depression. In the latter, during operation they may presented pressure and flow differences, which can result in water being wasted during a forest fire and increase the costs of implementing it should include the inclusion of more powerful hydraulics.

Every rural property is bounded by simple fences that are used to demarcation of the property area, in addition to the physical barrier for livestock, thus the system should use the pre-existing facilities to fix the fire detection system.

\subsection{Water reservoir subsystem: calculations and installation}

The water reservoir subsystem is a collection of reservoirs between each other, defined by the pump power and the water volume of the reservoir, which should generate a water jet of at least 8 meters over the fire. The greater the distance between the reservoirs, the greater the power of the pump and the volume of water in the reservoir, thus the minimum range of water jets will be preserved. Reservoir sizing, flow calculations $(\mathrm{Q})$, volume minimum of the reservoirs $(\mathrm{V})$, dimensions of the pipelines (D) and structure of the reservoir follow the technical specifications recommended by NBR 5626 (NBR, 2008), 13714 (NBR, 2003). The reservoir can be installed on a stable base, capable of withstanding the efforts on it, or in an independent structure (NBR 5626 and 13714), requiring water reservoirs to be constructed of concrete armed or metallic, being able to be made by other materials, provided that guarantee the resistances: to fire, mechanics, and weather.

The structure for the use of rainwater is standardized by the NBR 15527 (NBR, 2007), which provides from the projection of gutters and conductors to maintenance of the facilities.

\subsection{Water pipe subsystem: calculations and installation}

The structure of the piping subsystem must be able to withstand high temperatures reached during episodes of agroforestry fires and keep its operation unchanged. Therefore, it is recommended that the thermoplastic materials, should be installed only under / and below the ground, satisfying all requirements for resistance to internal pressure and mechanical and following the guidelines of NBR 13714. Meanwhile, the pipes must obey NBR 5580, NBR 5587 or NBR 5590, the steel connections to ASTM A 234, and PVC pipes and connections, the standards to be followed are NBR 5647 and NBR 10351.

\subsection{Water pumping subsystem: calculations and installation}

The water pumping subsystem must comply with the same criteria as the water reservoir subsystem, which should not be installed in just one location, because hydraulic pressure needs to generate water jets with a minimum range of 8 meters around the pen. Hydraulic pumps can be of the centrifugal type, submerged, peripheral, self-priming or injector, all with threephase connection. In the case of use of submerged pump, it must be placed inside the reserve container of water. It is also necessary to use pressurization pumps (Jockey) to compensate pressure losses at certain points, obeying the maximum flow 201/min, according to NBR 13714 of 2003. The automation of the pressurization (Jockey) to turn it on and off automatically and from the main pump (if it is not submerged) to only turn it on automatically must be done through of pressure switches installed according to figure 26, connected to the control panels and motor starting keys for each pump (NBR 13714, 2003). In the developed water jet system, the activation of the main pump is made by contactor on all types of hydraulic pumps.

To choose the power of the pump capable of producing water jets with minimum, it is necessary to consider the diameter of the pipe and the number of holes in the piping, moreover, consider the volume of the reservoir and the duration time in average firefighting. However, so far, according to the tests performed with the prototype; a submerged pump of $3 \mathrm{CV}$ of power, in a reservoir of 310 liters with a fence of approximately 1.5 meters in length, with $19 \mathrm{~mm}, 3 \mathrm{~mm}$ holes and $100 \mathrm{~mm}$ spacing, it was possible to create water jets with a little more than 8 meters of range, in a period of 1 minute and 20 seconds. 


\subsection{Electrical control subsystem}

The control subsystem is composed of a set of devices formed by both by auxiliary devices (meters-responsible for the operation of the hydraulic pump, solenoid valves - avoid water flow in the stretches where sensors did not identify the presence of fire) that promote greater control of the entire system, as well as the main ones (electromechanical components, hydraulic pumps, sensors, and electronic boards - controls the programming of the system). The signs systems interconnect the mechanical and electronic structure of the system, as their function is convert the signals sent by the sensors installed in the pens by activating the pumps hydraulics, and also, connecting the meters, when they detect / deactivate in the presence / absence of fire in the vicinity.

\subsection{Health alert subsystem}

As mentioned earlier, the fire-fighting system described in this article, allows the owner of the rural area or user of the system that the system be triggered at any time, without an operator / employee being present trim it. In addition, the system user can rely on the subsystem of system health alert. The alert subsystem is based on two technologies: GPSR, which sends a text message when the system against fires is activated, recommended for communication over long distances; via Bluetooth. Bluetooth is the simplest and cheapest way to send notifications, however, its range is limited (not recommended for long distances). Thus, system users can receive information and alerts while not physically in area affected by the fire. The main components of the control subsystem are the flame sensors, the Arduino board, the relay module, and the Bluetooth module (Figure 2).

Figure 2: a) Flame sensor; b) Arduino board, c) relay module; d) module Bluetooth.

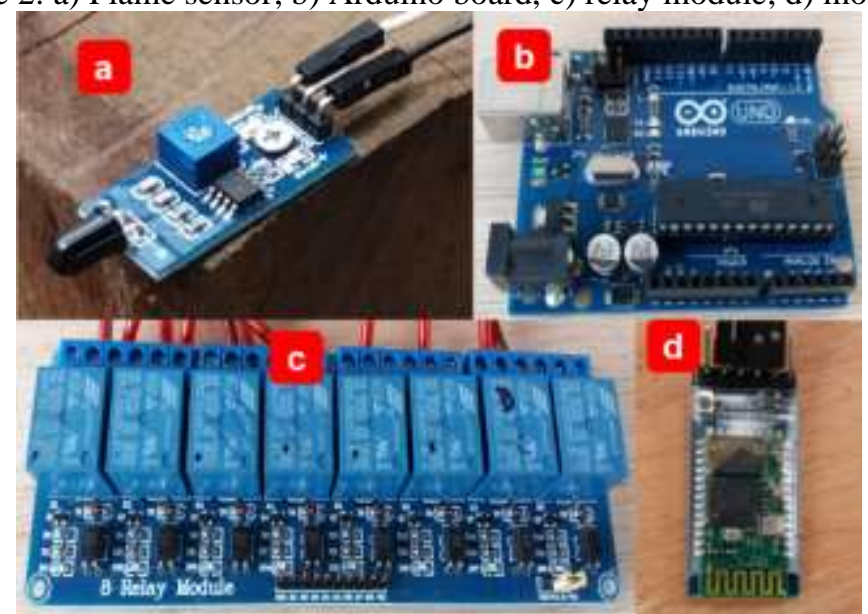

Source: Authors. 
Figure 3: On the right, a flame sensor being inserted into a PVC pipe and, on the right left, pipes with sensors (red circles) placed on the angular piles.

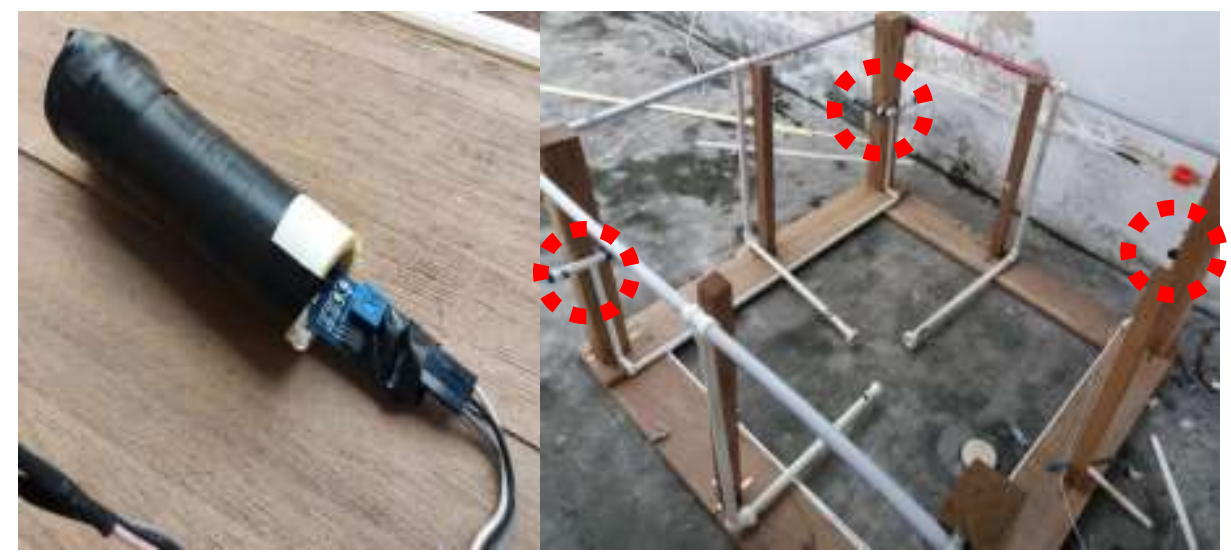

Source: Authors.

Figure 3 shows the prototype simulating the sensor that was used in the prototype. The prototype simulating at scale the enclosure of a rural property shown in Figure 3b, shows that sensors were installed at each of its ends and each sensor sensors work individually (Figura 3a), that is, if only one of the sensors detects the presence of fire. It sends an electronic signal to the Arduino board, resulting in activation of the hydraulic pump and opening of the solenoid valve only in that section, allowing the flow and activation of the water jets, as shown by the presence of sensors in Figure $3 \mathrm{~b}$. In addition, note that the hydraulic system is not only installed around the enclosure, but also possible to verify that the pipe runs along the ground floor and thus squirts into the ground, preventing it from drying out and being caught by fire quickly.

The Figure 4 shows the Arduino Uno sensor and the inputs it uses. The sensor board is powered by a USB cable connected to a $5 \mathrm{~V}$ power supply. Connections between components are made by male-female jumpers (colored wires) inserted into their terminals. In addition, the board has a bluetooth system, which through this it is possible to send information to the person responsible for the rural area, alerting him of possible fire alerts. At the same time, the alert system remotely allows the user to know what is happening on the property in real time.

Figure 4: Arduino Uno board with connections for sensors, relay modules and Bluetooth and the USB 5V power supply.

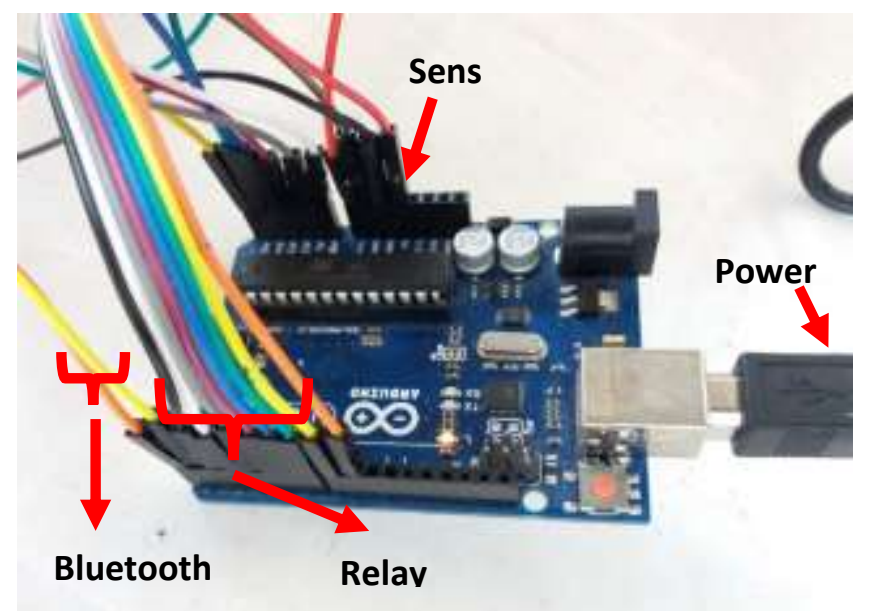

Source: Authors. 
Also, a 24V 8-channel relay module drives the hydraulic pump and of the solenoid valves (Figure 4). In the presence of fire, the plate receives the commands coming from the sensors and sends to the relay module, which activates the contactor of the submerged pump, opens the solenoid valves and the water flow is released to the direction where the presence of fire was detected, generating the compact water jets over the fire. A universal power supply for $120 \mathrm{~W}$ bi-volt notebooks is used to energize this module with $24 \mathrm{~V}$ voltage.

\subsection{Prototype Construction}

The efficiency of the fire detection and control system was verified through the results produced by the prototype built in smaller dimensions, used only for the purpose of validating the efficiency and functioning of the system combating fires near agricultural properties. The results and those of the construction of the system prototype are presented below.

First, a fixed wooden fence like the one built as delimitation of a rural property. Subsequently, hydraulic pipes with dimensions of $1.5 \mathrm{~m} / 9.05 \mathrm{~mm}$, (length and diameter, respectively) were installed in the upper part of the wooden structure. In addition, a set of holes of approximately $3 \mathrm{~mm}$ in diameter responsible for the water jets, were tabulation (Figure 5). In the simulations, a water reservoir with 310 liters capacity and fixed on the ground, a few meters away from the surrounded. Water circulates from the reservoir to the pipes with the aid of a submerged hydraulic pump of $3 \mathrm{CV}$, activated by a meter connected to the mains and to an 8-channel relay module.

Additionally, three industrial solenoid valves were used to control the flow of water from the reservoir to the pipes and in the pipe attached to the wooden fence, which will finally be triggered by the 5V Arduino Uno board which, in turn, receives signals from the fire detection sensors. As for the wires electrical, these are protected by flutes, while the valves, the components electronics, Arduino board and modules, a control box was used.

Figure 5: Specifications and measurements of the prototype with the specified dimensions.

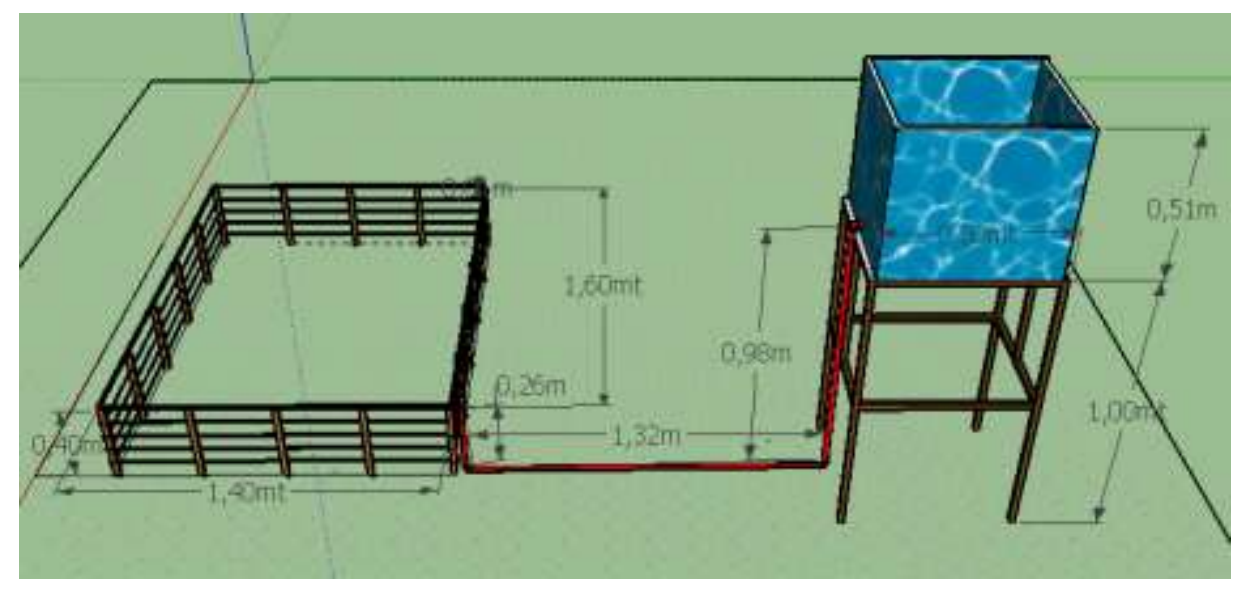

Source: Authors.

\subsection{Costs}

The materials used in the prototype had the characteristics and costs listed in the table below. The table is divided into materials purchased in stores physical and virtual, rental and workshop materials. The prototype, with an area of $2.25 \mathrm{~m}^{2}$, had an initial budget estimated at about $\$ 900.00$ and an actual cost of $\$ 500,00$. 


\section{Results}

During the earliest surveys on the components for the system, two fundamental issues for the water jets generation were estimated. The goal would be to generate jets with a 2 meters minimum perimeter range, to put out the fire. For this, the first point considered was the selection of a hydraulic pump of the centrifugal type, of $0.5 \mathrm{CV}$, to take water to the 4.5 meters of piping installed in the pen and which are responsible for creating the water jets. The enclosure is a square 1.5 meters long and wide and 0.7 meters high meters. The second point concerns the holes in the enclosure's pipes, which had holes made from a milling machine with a half inch disc and a $10 \mathrm{~mm}$ cut width $1 \mathrm{~mm}$. However, the first tests with the prototype showed that the centrifugal pump selected should be more powerful and the holes drilled in the fence piping should be smaller, as the water jets did not reach even ten centimeters apart (Figure 6).

Figure 6: On the left, control center and wiring of the solenoid valves and the painting of the enclosure structure with burnt oil.

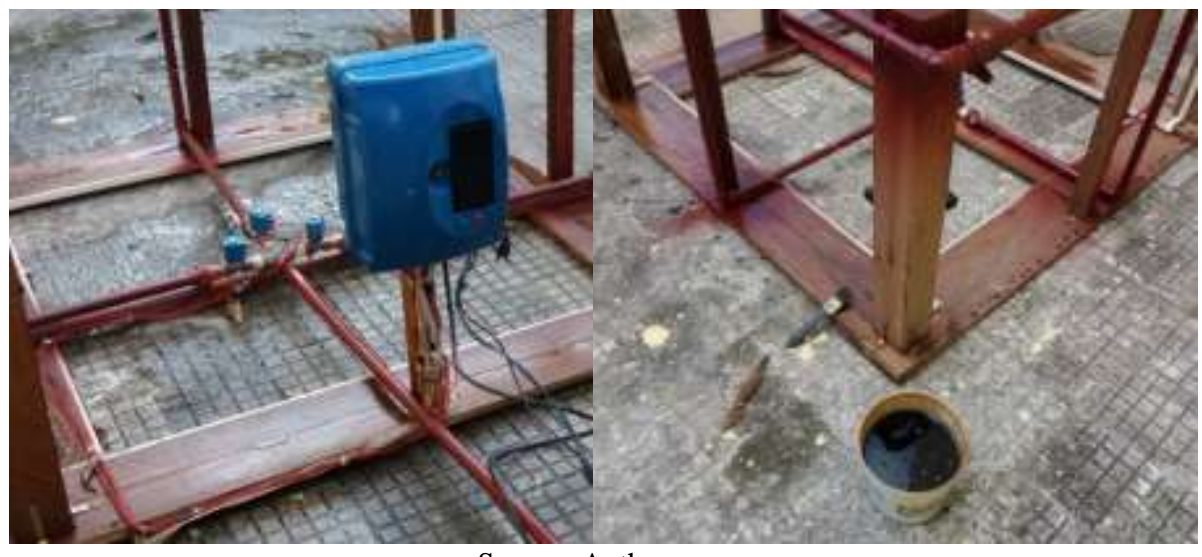

Source: Authors.

The change was necessary and the initial investment with these two points increased with the rent of another hydraulic pump, now of the submerged type of $3 \mathrm{CV}$ and the purchase of new PVC pipes, 19.05 in diameter (Figure 7). The holes in the new tubing were made with a $3 \mathrm{~mm}$ diameter drill. With the changes performed, a new battery of test was performed, and a significant improvement was observed when launching the water jets, reaching up to 8 meters away, for a 1.5-meter-long pipe. For all fencing tubing, from 4.5 meters in length, the water jets arrived at 3 meters, varying this distance depending on the increase or decrease in the pipe length.

Figure 7: a) Front side view of the finished prototype; b) Rear view of the prototype finished.

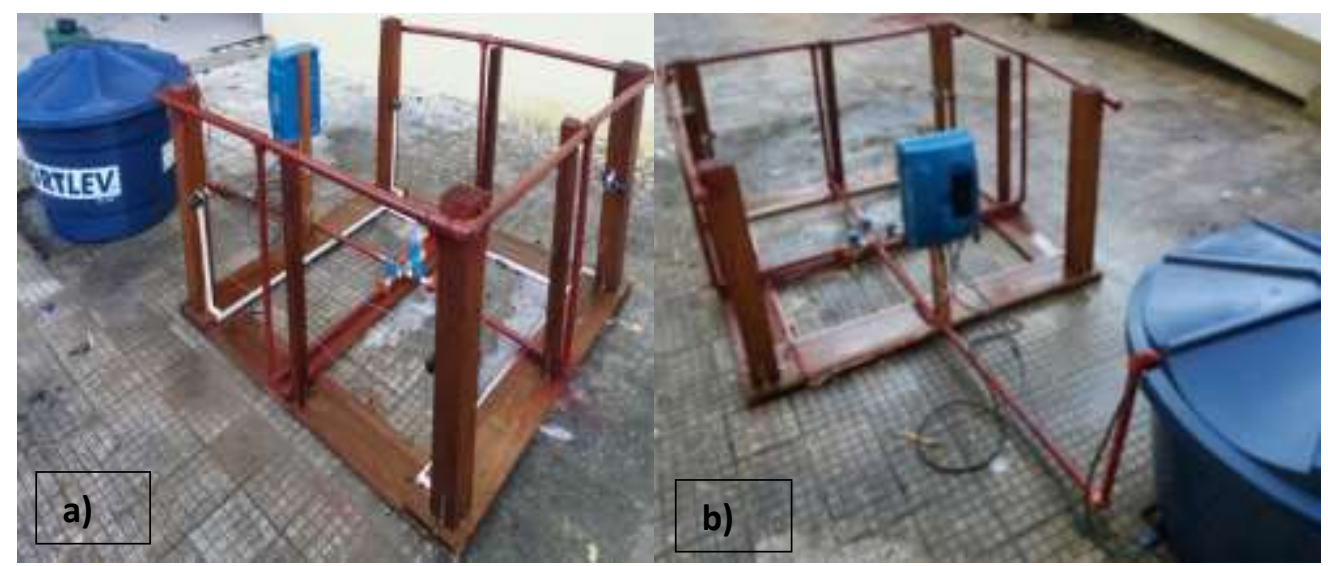

Source: Authors. 
Due to the wide variations seen in the range of the water jets and in the water flow towards the enclosure where there was no fire, a new change was made in the original model of the prototype, adding three solenoid valves between the connection of the submerged pump and the enclosure pipes.

The three modifications mentioned and carried out in the prototype were crucial for bring more control and automation to the entire field system (Figure 7). The changes guaranteed compact jets of water of about two meters, without major variations in reach distance, and greater water savings in the reservoirs, due to the installation of solenoid valves, resulting in better performance of the prototype during the fighting fires. However, tubes with holes installed in pens had to undergo adjustment of the holes inclination to allow them to generate water jets closer to the enclosure, and no more than two meters away, as previously intended, as the sensors used in this work detected the presence of fire at most 40 centimeters away, extinguishing what resulted in the reach of our main objective, which is to put out the fire.

\section{Final Considerations}

In the last decades, controlled fires or not, are a sad reality which has caused destruction in rural and forest areas. Despite attempts to stopping fires, fire brigades and rural producers have shown a certain deficiency in fighting them. Thus, this work showed the construction of a prototype of firefighting system, which can be installed in the delimitation of rural areas and preservation, considering the possible environmental impacts and defining the best cost-benefit plan for your installation. The results of studies and tests with the prototype, showed the best ways to guarantee the primary resources for the functioning of the system, which are water and electricity. With this, it will be possible to obtain the efficiency of the system in combating the foci of fire at any time of the day and promote economic and environmental sustainability of region.

The devices used in the system can be installed according to the range of defense line / installation area, in addition to the power of the pumps hydraulics, number of water reservoirs, as well as the volume of water. The subsystems that compose it never work in isolation, being necessary the communication between them so that there are no failures when fighting possible fires. The main function of the whole mechanism is to make the water in the reservoirs flow through the pipes with high flow and pressure installed generating jets of medium and long-range water, eliminating the threat of fire that advances over the local.

The simple generation of water jets has a cost to be paid, but this cost is not greater than the annual losses that burning and forest fires cause ruralists, which can lead many people to acquire the system and prefer to pay for installation and maintenance expenses than seeing months or years of production and story to ash in a few minutes. Therefore, the commitment to security, protection, modernization, and sustainability of rural areas is proposal. In addition, the firefighting system is completely unassisted, being also connected to sensors that are activated via Bluetooth to which they send messages to the registered cell phones of those responsible for the area/or rural property, when it is in danger of emitting fire, activating the system, and sending warnings via mobile.

As the system was designed, it is only intended to fight fire when it is around the enclosure. As future work, it is intended to attach soil moisture detectors to the system, so that they can check how dry the soil is, and so, if it is, the system will be activated by releasing water to its surroundings, acting preventively.

\section{References}

Abreu, F. A., \& Souza, J. S. A. (2016) Space-time dynamics of fire outbreaks in two indigenous lands in the state of Mato Grosso: a geospatial approach on the dynamics of fire use by Xavantes and Bororos. Forest and Environment, 23 (1), 1-10.

Abatzoglou, J. T., Kolden, C. A., Balch, J. K. \& Bethany A., \& Bradley, B. A. (2016). Controls on interannual variability in lightning-caused fire activity in the western US. Envirinmental Research Letters, 11(4), 045005. 
Adams, C. \& Murrieta, R. S. S. (2008). Slash and burn agriculture and tropical forests in a changing world. Bulletin of the Museu Paraense Emílio Goeldi Human Sciences, Belém- PA, 3(2).

Bretos, A. L. K. \& Pereira, J. A. C. (2012). Temporal analysis of burning in the park State of Jalapão, Tocantins, from 1997 to 2011. INPE: Ministry of Science and Technology.

Cochrane, M. (2010) Tropical fire ecology: climate change, land use and ecosystem dynamics, Springer Science \& amp, Business Media.

Corrêa, A. V. S., Juncal, A. M. S., Castanheiro, B. M., Borges, D. S., Amaral, G. N., Santos, G. S., Bessa, N. G. D. \& Amaral, S. H. R. (2012). Relação das queimadas e os casos de doenças respiratórias em crianças e idosos na época da seca no Tocantins. Revista de Patologia do Tocantins, 8(1).

Dowdy, A. J. \& Mills, G. A. (2012). characteristics of lightning-attributed wildland fires in south-EAST Australia. International Journal Of Wildland Fire, 21(5) 521-524.

Gioda A., Tonietto G. B. \& Leon A. P. (2019). Exposição ao uso da lenha para cocção no Brasil e sua relação com os agravos à saúde da população. Ciência \& Saúde Coletiva, 24 (8), 3079-3088.

Ganteaume A., \& Syphard A. D. (2018). Ignition Sources. In: Manzello S. (eds) Encyclopedia of Wildfires and Wildland-Urban Interface (WUI) Fires. Springer, Cham.

Gil, A. C. Como elaborar projetos de pesquisa. (5a ed.), Atlas.

Jesus, A. G., Parente, T. G., Cançado, A. C. \& Gomes, H. (2020). The practice of burning culture agricultural activities and their implications for the state of Tocantins. Policy Review Public, 24(1).

Lakatos, E. M., \& Marconi, M. A. Metodologia científica. (6a ed.), Atlas.

Marques, R. J. \& Sobrinho, W. F. R. C. (2020) Detecção das ocorrências de focos de queimadas e produção de mapas de calor em Timon, MA. Revista Geonorte, 11(37), 210-228.

Melo, A. S., Justino, F., Lemos, C. F., Sediyama, G., \& Ribeiro, G. (2011). Suscetibilidade do ambiente a ocorrências de queimadas sob condições climáticas atuais e de futuro aquecimento global. Revista Brasileira de Meteorologia, 26(3), 401-418.

Medeiros, M. B. \& Fiedler, N. C. (2004). Incêndios florestais no Parque Nacional da Serra da Canastra: desafios para a conservação da biodiversidade. Ciência Florestal, Santa Maria, 14(2), 157-168.

Muñoz, R. V. (2000). La Definición de Incendio Forestal. La Defensa Against Forestales fires Fundamentals and Experiences. A. G. Brage. Madrid, McGrawHill / Interamericana de España, 13-16. 2000.

Nascimento-e-Silva, D. Manual de Redação para Trabalhos Acadêmicos: position paper, ensaios teóricos, artigos científicos e questões discursivas. $1^{\text {a }}$ edição. Atlas, São Paulo, 2012.

NBR 13714, Alimentação natural de reservatório por adufa, Sistemas de Hidrantes e de Mangotinhos para Combate a Incêndio.

Neto, A. P. M., Batista, A. C., Soares, R. V., Biondi, D. \& Morais, R. L. (2017). Evaluation of the hot spots and the Monte Alegre formula in the Chapada dos National Park Guimarães. Brazilian Forestry Research, 37, 535-543.

Neves, L. F. de S., Marimon, B. S., Anderson, L. O. \& Neves, S. M. A. S. (2018). Dinâmica de fogo no Parque Estadual do Araguaia, Zona de Transição Amazônia Cerrado. Revista RaeGa. 44, 85 -103.

Pezzatti, G. B., Zumbrunnen, T., Bürgi, M., Ambrosetti, P., \& Conedera, M. (2013). Fire regime shifts as a consequence of fire policy and socio- economic development: An analysis based on the change point approach. Forest Policy and Economics, 29, 7-18.

Pinto Jr., O. \& Pinto, I. R. C. A. (2000). Tempestades e relâmpagos no Brasil. Instituto Nacional de Pesquisas Espaciais.

Rego, A. K. C., \& Kato, O. R. (2018). Agricultura de corte e queima e alternativas agroecológicas na Amazônia. Novos Cadernos NAEA, 20(3), 203-224.

Ribiero, G. A. \& Bonfim, V. R. (2000). Incêndio florestal versus queima controlada. Revista Ação Ambiental, 12, 8-11.

Santiago, L. A. N. \& Lopes, R. S. 2021.Impactos na saúde humana devido à emissão de aerossóis causada por queimadas /impacts on human health due to the emission of aerosols caused by burns. Brazilian Journal of Development, 7(1).

Silva Filho, E. B., Teles, L. J. S. \& Santos Neto, 1. A. (2009). ocorrências de focos de calor no estado de Rondônia em 2007. Sociedade \& Natureza, 21(2), 123-140.

Silva, T. P., Pontes, A. N., \& Amorin, I. A. (2020). Alternatives to the use of fire in agriculture as how to mitigate burning in the Amazon. Research, Society and Development, 9(8), e387985938.

Soares, J. A. P. \& Peixinho, D. M. (2020). Fogo no Cerrado e a vulnerabilidade em assentamentos rurais. Campo-território: Revista de Geografia Agrária, 5(37), 87- 108.

Spera, S. T., Reatto, A., Correia, J. R. \& Silva, J. C. S. (2000). Características físicas de um Latossolo Vermelho-escuro no cerrado de Planaltina, DF, submetido à ação do Fogo. Pesquisa Agropecuária Brasileira, 35(9), 1817-1824.

Stephens, S. L. (2005). Forest fire causes and extent on United States forest service lands. International Journal of Wildland Fire. 14, 213-222. 
Research, Society and Development, v. 10, n. 12, e574101220952, 2021

(CC BY 4.0) | ISSN 2525-3409 | DOI: http://dx.doi.org/10.33448/rsd-v10i12.20952

Stone, L. F. \& Silveira, P. M. (2001). Efeitos do sistema de preparo e da rotação de culturas na porosidade e densidade do solo. Revista Brasileira de Ciência do Solo, 5(2), 395-401. 